\title{
O uso da biologia molecular na elucidação da patogenicidade dos canceres
}

\section{Role del Consumo de Alcohol y Antioxidantessobre la Metilación Global del ADN y Cáncer}

Sandoval, C.; Vásquez, B. Souza-Mello, V.; Mandarim-De-Lacerda, C. A. \& Del Sol, M. Rol Del Consumo De Alcohol Y Antioxidantes Sobre La Metilación Global Del ADN Y Cáncer. Int. J. Morphol., 36(1):367-372, 2018.

É conhecido que o alcoolismo é uma doença crônica, que acarreta não apenas a dependência física, mas também psicologia. É estimado que cerca de $10 \%$ da população mundial é dependente desse vício.

O álcool de maneira excessiva traz inúmeros efeitos maléficos para o organismo como: doenças hepáticas, doenças cardiovasculares, défices neurológicos e cognitivos, alterações comportamentais e câncer. Além dos efeitos mencionados, a deficiência nutricional é muito comum nos usuários dessa droga. Os alcoólatras crônicos exibem, em muitos casos, exaustão de lipotrópicos, originando, possivelmente, uma produção alterada de S-adenosilmetionina (SAM), resultando em modificações na metilação do DNA.

Não apenas isso altera a codificação do DNA do indíviduo, o etanol é capaz de originar disturbios que afetam a expressão gênica das vias reguladoras da sinalização celular, afetando a regularização e transcrição gênetica do usuário.

O álcool é um fator de risco importante no câncer, visto que essa substância aumenta o aparecimento de agentes oncogênicos e reprime a capacidade das células de agirem em homeostasia, tornando insustentável o reparo de DNA, aumentando a probabilidade de mutações oncogênicas.
Gabriela Lopes dos Santos ${ }^{1}$ ${ }^{1}$ Mestranda em Estomatologia na Faculdade de Odontologia de Araçatuba- Universidade Estadual Julio de Mesquita Filho

O estudo do mecânismo epigenético é realizado para analisar as mudanças hereditárias no padrão de expressão gênica. Embora a sequência de DNA seja bastante permanente, as alterações epigenéticas são dinâmicas ao longo da vida dos individuos, e podem ser intensamente influenciadas por fatores externos. Sabendo disso, estudos mostram que o meio ambiente pode alterar a regulação do RNA não-codificante, microRNA, remodulação de cromatina, modificação de histonas e metilação do DNA, que são indispensáveis e essenciais na regulação génetica de todos os mamíferos.

A metilação do DNA é resultado da transferência do radical livre metil $(\mathrm{CH} 3)$ na base nitrogenada citosina. Esse processo é catalisado por uma família de enzimas denominadas DNA-metiltransferases (DNMT). As funções das DNMTs são efetivas para a concepção dos padrões de metilação do DNA das células proliferativas. Durante o consumo excessivo de álcool reduz consideravelmente a formação de DNMT e SAM, sem a formação desses, não há metilação do DNA e histonas.

Mas como sabemos se o individo está sofrendo modificações da metilação do DNA? Alcoólatras crônicos geralmente têm níveis de homocisteína (Hcy) elevados. Porém, o que é Hcy? A homocisteína, formada a partir da me- 
tionina hepática, é metabolizada nas vias de desmetilação e de transulfuração, sendo que seus valores plasmáticos e urinários se refletem na síntese celular. Sua alteração caracteriza as diferenças nas vias metabólicas, principalmente de natureza genética. ${ }^{1}$ Neste contexto, o etanol pode promover novos padrões de metilação, causando a mutação do DNA, que poderia contribuir também à carcinogênese induzida pelo álcool.

O etanol é metabolizado em acetaldeído pela ação de algumas enzimas, sendo oxidado a acetato pela ação de acetaldeído desidrogenase (ALDH). O ALFH é altamente tóxico e cancerígeno para nosso organismo, quando nosso tecido é exposto a essa substância após a ingestão de álcool, sendo a quantidade diretamente proporcional ao dano, irá afetar no processo carcinogênico.

O DNA é usado como biomarcado para ajudar na detecção do câncer, com isso melhorar o prognóstico e resposta a possíveis tratamentos. Mesmo com inúmeras pesquisas e estudos in vivo e in vitro, tentando elucidar os efeitos adversos causados pelo consumo de álcool e seu mecanismo molecular que leva a alterações no padrão da metilação, pouco se aborda sobre o assunto, sendo indispensáveis maiores estudos em nível de biologia molecular.

O estudo do mecânismo epigenético exemplifica a ação genética da mutação celular.
Com isso, estudos altamente específicos mostram a ação explicita de fatores oncongênicos que causam o câncer em diversas áreas. No câncer bucal, não é diferente. O The Cancer Genome Atlas Network em 2015 analisou 279 carcinomas de células escamosas de cabeça e pescoço associados ao vírus oncogênico do HPV, para fornecer um panorama de alterações genômicas somáticas. ${ }^{2}$

No Brasil, pouco se efetua pesquisas em nível da biologia molecular, sendo assim uma área bastante escassa e muito importante para o entendimento da patogenicidade dos inúmeros tipos de câncer.

\section{REFERÊNCIAS}

1. Neves LB, Macedo DM, Lopes AC. Homocisteína. J Bras Patol e Med Lab [Internet]. 2004 Oct [cited 2019 Mar 6];40(5):311-20. Available from: http://www.scielo.br/scielo.php?script=sci_ arttext\&pid=S1676-24442004000500006\&lng= pt\&nrm=iso\&tlng=pt

2. Network TCGA. Comprehensive genomic characterization of head and neck squamous cell carcinomas. Nature [Internet]. Nature Publishing Group; 2015 Jan 29 [cited 2019 Mar 6];517(7536):576-82. Available from: http:// www.nature.com/articles/nature14129

Submetido em: 30-3-2019

Aceito em: 22-5-2019 